\title{
Effect of tick salivary gland extract on the cytokine production by mouse epidermal cells
}

\author{
Jitka Pechová, Jan Kopecký and Jiří Salát
}

Institute of Parasitology, Academy of Sciences of the Czech Republic, and Faculty of Biological Sciences, University of South Bohemia, Branišovská 31, 37005 České Budějovice, Czech Republic

Key words: Ixodes ricinus, salivary gland extract, Borrelia afzelii, mouse epidermal cells, cytokines

\begin{abstract}
Previous studies have demonstrated that both tick saliva and Borrelia burgdorferi sensu lato antigens modulate the cytokine response of the host. In this paper, the effect of salivary gland extract (SGE) from Ixodes ricinus (L., 1758) ticks on cytokine production by primary cultures of mouse epidermal cells stimulated with Borrelia afzelii Canica, Nato, du Merle, Mazie, Baranton et Postic, 1993 spirochetes was analysed. Epidermal cells were derived from $\mathrm{C} 3 \mathrm{H} / \mathrm{HeN}$ mice, susceptible to Lyme disease, and $\mathrm{BALB} / \mathrm{c}$ mice, which are resistant. In cultures from $\mathrm{C} 3 \mathrm{H} / \mathrm{HeN}$ mice, SGE down regulated production of tumour necrosis factor alpha (TNF- $\alpha$ ) and up regulated Th2 cytokine, interleukin 4 (IL-4). Cultures from BALB/c mice produced higher basal levels of monitored cytokines, but their production was affected by SGE a different way. While Th2 cytokines IL-6 and IL10 were down regulated, the effect on TNF- $\alpha$ and IL-4 was ambiguous. These results indicate that the effect of tick saliva on the epidermal cells of Lyme disease-susceptible $\mathrm{C} 3 \mathrm{H} / \mathrm{HeN}$ mice mirrors its effect on other cells of the immune system.
\end{abstract}

The common tick Ixodes ricinus (L., 1758) is one of the most important vectors of human pathogens like the spirochete Borrelia burgdorferi sensu lato and tickborne encephalitis virus. The first part of the immune system that tick saliva and the pathogen come into contact with is the host skin. Skin-associated lymphoid tissue (SALT, Streilein 1983) represents a tertiary lymphoid organ with an important function in defence against skin-invading pathogens. SALT is regulated by cytokines produced by skin cells themselves or immigrating inflammatory cells. Cytokines orchestrate the structure of cell subpopulations in the skin, cell migration within the skin, maturation and differentiation of individual cell subpopulations and the presentation of antigen by cells with this purpose (Enk et al. 1993).

Borrelia burgdorferi sensu lato, a group of genetically diverse spirochetes, is the causative agent of Lyme disease. Ticks deposit a small number of bacteria in the skin of the host animal during feeding, leading to a local infection. Bacterial dissemination and colonisation of many different organs (depending on tissue tropism of different Borrelia species) may follow and can cause multifactorial multisystem degenerative disorder (Steere 1989).

A model of murine Lyme borreliosis indicates that the host immune response can influence the outcome of disease such as the severity of arthritis. It has been demonstrated that infected BALB/c mice develop mild arthritis, whereas $\mathrm{C} 3 \mathrm{H} / \mathrm{HeJ}$ mice suffer from severe arthritis (Barthold et al. 1990). In these infected strains, production of Th2 cytokine interleukin 4 (IL-4) correlated to resistance, whereas an increase in Th1 cytokine interferon gamma (IFN- $\gamma$ ) correlated to susceptibility (Matyniak and Reiner 1995).

Borrelia spirochetes express several outer surface lipoproteins that induce a strong inflammatory response in the host. Inflammatory signalling by Borrelia lipoproteins, leading to the cytokine production, is mediated by Toll-like receptor 2 (Hirschfeld et al. 1999).

Interaction between the arthropod vector and the host has profound implications for the eventual transmission of tick-borne pathogens. Tick feeding and accompanying modulation of the host immune response by tick saliva greatly influence the infectivity and dissemination of the spirochete (Pechová et al. 2002). In addition to antihaemostatic and vasoactive effects, tick saliva possesses broad immunomodulatory activities affecting both innate and adaptive immunity of the host (Wikel 1999). Molecules in tick saliva modulate host cytokine balance and shift cytokine production towards Th2 cytokines (Kopecký et al. 1999, Schoeler et al. 1999). Up regulation of Th2 cytokines in parallel with suppression of Th1 lymphocyte and macrophage cytokine production allows ticks to decrease a specific skin inflammatory response, characterised as a cutaneous basophile hypersensitivity (Ferreira et al. 2003).

Despite of some anti-inflammatory activity of tick saliva, tick feeding induces an acute inflammatory response in the host skin, characterised by an influx of inflammatory cells like granulocytes and mononuclear cells, into the tick feeding site (Wheeler et al. 1989, Mbow et al. 1994a). Repeated infestation leads more readily to degranulation of mast cells after contact with tick saliva antigens, the outnumbering of $\mathrm{CD} 4+\mathrm{T}$ 
lymphocytes over CD8 $+\mathrm{T}$ cells and an increase in local expression of MHC II and intercellular adhesion molecules (Mbow et al. 1994b). In the infested skin, increased expression of mRNA specific for proinflammatory cytokines interleukin 1 (IL-1) and tumour necrosis factor alpha (TNF- $\alpha$ ) was recorded (Mbow et al. 1994b). The number of IFN- $\gamma$ mRNA-positive and IL-2 mRNA-positive cells increased with the number of infestations, whereas the amount of IL-4 mRNA-positive cells was not affected or decreased after repeated feeding.

Although there is rather extensive information about the effect of tick saliva on cytokine production by immunocompetent cells derived from spleen or lymph node cells, little is known about the effect of tick saliva on cytokine production by epidermal cells. As the skin represents the place of first contact of tick saliva antigens and transmitted pathogens with the host immune system, we tried to induce cytokines in cultures of epidermal cells and analysed the effect of immunomodulatory molecules in salivary gland extract (SGE) upon induction. Live Borrelia afzelii Canica, Nato, du Merle, Mazie, Baranton et Postic, 1993 spirochetes were used as cytokine inducers.

\section{MATERIALS AND METHODS}

Salivary gland extract. Ixodes ricinus females originated from the pathogen-free colony of the Institute of Parasitology, Academy of Sciences of the Czech Republic, České Budějovice. After 5-6 days of feeding on guinea pigs, ticks were removed and their salivary glands dissected under sterile conditions. After washing in phosphate-buffered saline (PBS), the salivary glands were homogenised by sonication and clarified at $10,000 \mathrm{~g}$ for $10 \mathrm{~min}$. The protein concentration was determined spectrophotometrically by Bradford's method. Aliquots of SGE were stored at $-70^{\circ} \mathrm{C}$. SGE at a concentration of 20 $\mu \mathrm{g} / \mathrm{ml}$ had no effect on mouse lymphocyte viability as determined by trypan blue exclusion test.

Mice. Specific pathogen-free mice were purchased from Charles River (Sulzfeld, Germany); 8-12 weeks old C3H/HeN and $\mathrm{BALB} / \mathrm{c}$ females were used in the study.

Bacteria. Spirochetes of the low-passage CB 43 strain of B. afzelii (Štěpánová-Tresová et al. 1999) were grown in BSK$\mathrm{H}$ medium supplemented with $6 \%$ rabbit serum (Sigma) without antibiotics. Before use, the spirochetes were centrifuged at 5,000 g $10 \mathrm{~min}$ and washed with sterile PBS.

Primary epidermal cell culture. Epidermal cells were prepared by trypsinisation of mouse trunk skin (Elbe et al. 1997). Mice were killed by cervical dislocation. The skin of the trunk was shaved, rinsed with $70 \%$ ethanol, removed by scissors and immediately placed epidermal side down in a Petri dish with sterile PBS. Hypodermis fat and tissue were ablated with a scalpel. Small pieces of cleared skin were moved dermal side down into $1 \%$ trypsin in PBS and incubated for $30 \mathrm{~min}$ at $37^{\circ} \mathrm{C}$. After that, the epidermis was peeled in RPMI 1640 medium supplemented with $10 \%$ foetal calf serum (FCS) and triturated with a sterile tissue grinder. The cell suspension was washed twice in PBS, counted and resuspended in RPMI 1640 medium supplemented with $10 \%$ FCS, $0.1 \mathrm{mM}$ nonessential amino acids, $1 \mathrm{mM}$ sodium pyruvate, $50 \mu \mathrm{M}$ 2-mercaptoethanol and antibiotics. Cells were seeded in 96-well tissue culture plate $\left(2 \times 10^{5}\right.$ cells/well $)$ and cultivated at $37^{\circ} \mathrm{C}$ and $3.5 \% \mathrm{CO}_{2}$ for several days to allow confluent monolayer to form.

Induction of cytokines. For experiments, plates with confluent monolayer were used, in which the viability of cells was at least $80 \%$. Cells were stimulated with Borrelia spirochetes at various ratios (from 100 spirochetes per cell to 0.1 spirochete per cell) in fresh RPMI 1640 culture medium with antibiotic mixture for Borrelia (Sigma). SGE was added $2 \mathrm{~h}$ before spirochetes at a final concentration of $20 \mu \mathrm{g} / \mathrm{ml}$. Supernatants for ELISA tests were harvested $24 \mathrm{~h}$ later and stored at $-70^{\circ} \mathrm{C}$. All combinations were set up in triplicate.

Cytokine detection. Antibody-sandwich enzyme-linked immunosorbent assays (ELISA) were performed using matched pairs of monoclonal antibodies (MAbs). Wells of high-binding, flat-bottom EIA/RIA plates (Corning Incorporated, Corning, NY, USA) were coated with $50 \mu 1$ of capture antibody overnight at $4{ }^{\circ} \mathrm{C}$. Antibodies were diluted in a coating solution $\left(0.1 \mathrm{M} \mathrm{NaHCO}_{3}, \mathrm{pH} 8.2\right)$ to a concentration of $1-$ $10 \mu \mathrm{g} / \mathrm{ml}$. After blocking with PBS and $10 \%$ newborn calf serum (NCS) for $2 \mathrm{~h}$ at room temperature, samples were added $(50 \mu \mathrm{l} /$ well $)$ and incubated overnight at $4^{\circ} \mathrm{C}$. Plates were then incubated with biotinylated MAbs $(100 \mu \mathrm{l} /$ well $)$ diluted in PBS and $10 \%$ NCS to $0.2-2 \mu \mathrm{g} / \mathrm{ml}$ for $45 \mathrm{~min}$ at room temperature. Subsequently, $100 \mu 1$ of 1,000-fold diluted streptavidin peroxidase (Sigma) was added and incubated for 30 min at room temperature. The substrate for the enzymatic colour reaction was orthophenylenediamine (Sigma) with hydrogen peroxide $(100 \mu \mathrm{l} /$ well $)$. After $10 \mathrm{~min}$ of incubation, the reaction was stopped with $100 \mu \mathrm{l}$ of $2 \mathrm{M} \mathrm{H}_{2} \mathrm{SO}_{4}$ and measured with an ELISA spectrophotometer (Multiskan MCC 340, Labsystems Oy, Helsinki, Finland) at $490 \mathrm{~nm}$. After each incubation the plates were washed at least three times with $0.05 \%$ Tween 20 in PBS. Serial dilutions of recombinant cytokines (R\&D Systems, Minneapolis, MN, USA) were used to generate the cytokine standard curves. The following capture and detection antibodies were used in cytokine ELISAs: IL-4, clones BVD4-1D11 and BVD6-24G2 (Serotec, Kidlington, UK); IL-6, clone MP 520F3 and goat polyclonal antibody (R\&D Systems); IL-10, clones JES5-2A5 and SXC-1 (PharMingen, San Diego, CA, USA); GM-CSF, clone MP122E9 and goat polyclonal antibody (R\&D Systems); TNF- $\alpha$, clones G281-2626 and MP6-XT3 (PharMingen); IFN- $\gamma$, clones 37801.11 (R\&D Systems) and XMG1.2 (PharMingen); IL-1 $\beta$, clone 30311.11 and goat polyclonal antibody (R\&D Systems); IL-13 clone 38213.11 and goat polyclonal antibody (R\&D Systems).

Statistical analysis. The experiments were conducted in triplicate and repeated several times to assess the reproducibility of the results. The significance of any differences obtained between experimental groups was evaluated by the Student's $t$-test.

\section{RESULTS}

To test the ability of mouse epidermal cells to produce measurable levels of cytokines, various ratios of 

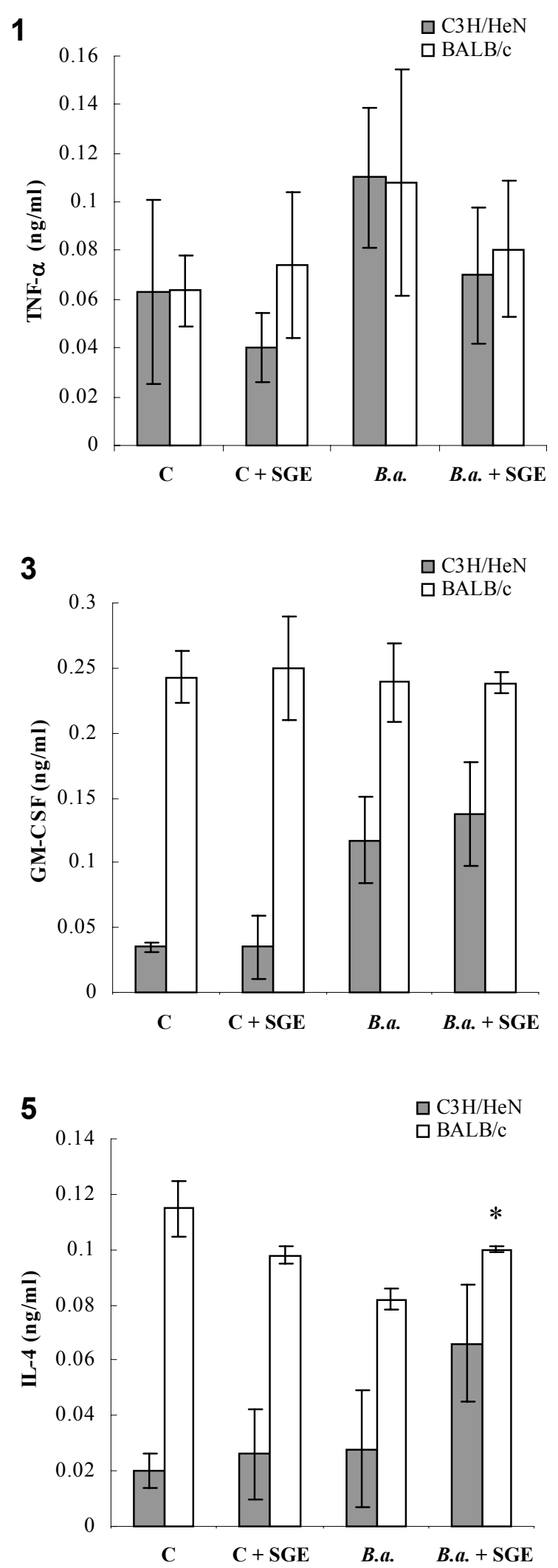
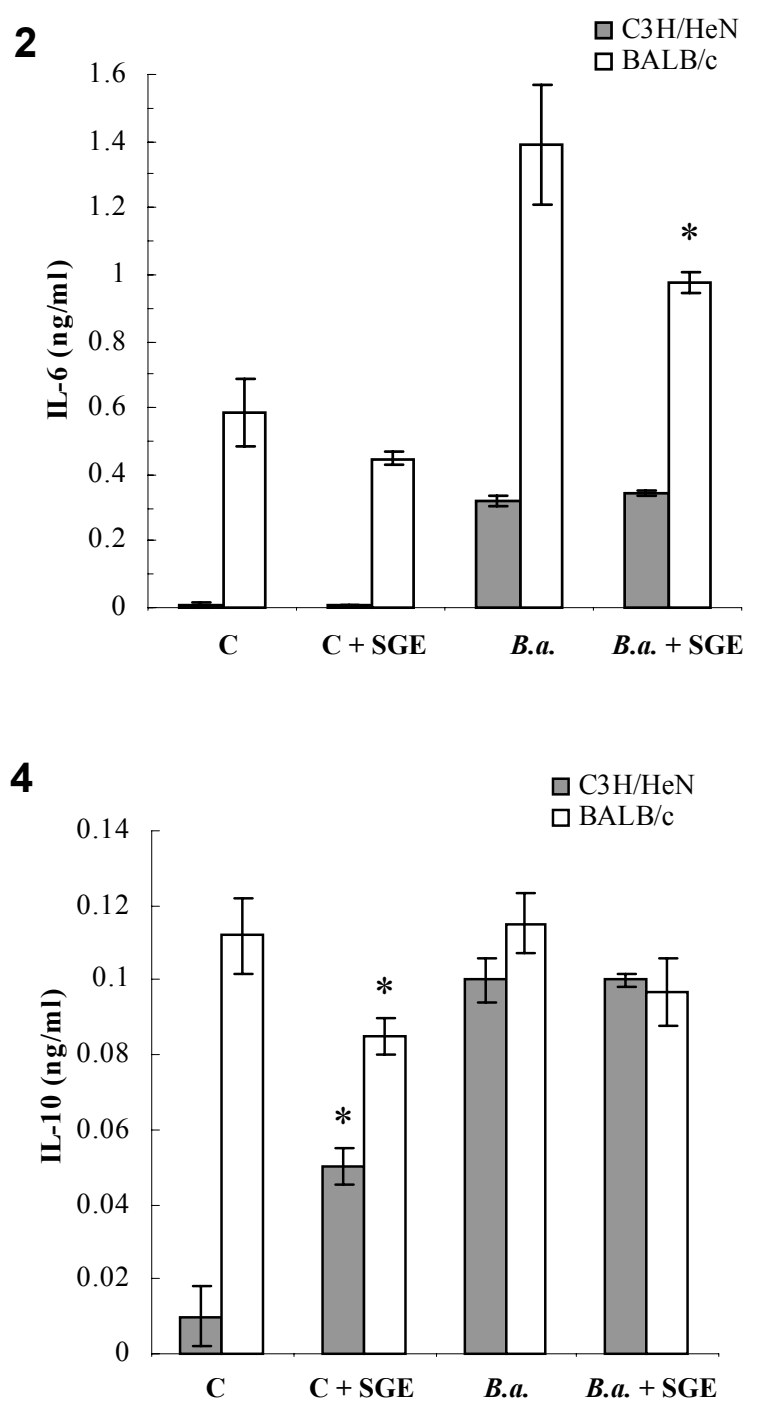

Figs. 1-5. The effect of salivary gland extract (SGE) from partially fed Ixodes ricinus females on the production of cytokines by cultures of $\mathrm{C} 3 \mathrm{H} / \mathrm{HeN}$ and $\mathrm{BALB} / \mathrm{c}$ mouse epidermal cells stimulated with Borrelia afzelii spirochetes (B.a.). Cells were treated with SGE $(20 \mu \mathrm{g} / \mathrm{ml}) 2 \mathrm{~h}$ before addition of live spirochetes (one spirochete per one epidermal cell). C - control, untreated cells. Supernatants for cytokine ELISA were harvested $24 \mathrm{~h}$ after stimulation with the spirochetes. Each column represents an average of three cultures \pm SD. Fig. 1. TNF- $\alpha$. Fig. 2. IL-6. *The difference between spirochetestimulated and spirochete + SGE-stimulated groups was significant at $\mathrm{P}<0.05$. Fig. 3. GM-CSF. Fig. 4. IL-10. *The difference between control and SGE-treated groups was significant at $\mathrm{P}<0.05$. Fig. 5. IL-4. *The difference between spirochete-stimulated and spirochete + SGE-stimulated groups was significant at $\mathrm{P}<0.05$. 
spirochetes to epidermal cells $(0.1: 1$ to $100: 1)$ were used for cytokine induction. The ratio of $1: 1$ was the smallest one inducing production of cytokines TNF- $\alpha$, IL- 4 , IL6, IL-10 and GM-CSF in epidermal cell cultures derived from both mouse strains used (data not shown). In spirochete-stimulated cultures, no measurable production of IFN- $\gamma$, IL-1 $\beta$ and IL-13 was detected.

Both $\mathrm{C} 3 \mathrm{H} / \mathrm{HeN}$ and $\mathrm{BALB} / \mathrm{c}$ mice produced comparable levels of TNF- $\alpha$ after stimulation with $B$. afzelii spirochetes at the multiplicity of infection 1 . The suppressive effect of SGE on this cytokine was recorded in spirochete-stimulated cultures of epidermal cells from both strains of mice (Fig. 1).

In contrast, $\mathrm{BALB} / \mathrm{c}$ epidermal cells produced higher levels of Th2 cytokines (IL-4, IL-6, IL-10) and GM$\mathrm{CSF}$ compared with those produced by $\mathrm{C} 3 \mathrm{H} / \mathrm{HeN}-$ derived cells, including spontaneous production by nonstimulated cells (Figs. 2-5). However, stimulation of $\mathrm{BALB} / \mathrm{c}$ cells with live spirochetes did not increase production of the above-mentioned cytokines above the control level, with the exception of IL-6. Production of this cytokine was markedly suppressed in SGE-treated cultures (Fig. 2). While IL-10 was down regulated in SGE-affected cells (Fig. 4), SGE effect on the production of the other Th2 cytokine IL-4 was controversial (Fig. 5). In non-stimulated control cultures of epidermal cells, SGE slightly down regulated production of IL-4, whereas this cytokine was up regulated in spirochetestimulated cultures.

Although epidermal cells from $\mathrm{C} 3 \mathrm{H} / \mathrm{HeN}$ mice produced generally lower levels of cytokines, their reaction to borrelia stimulus was stronger. For example, the level of IL-10 increased ten-fold compared to non-stimulated controls. IL-6 increased 32-fold and GM-CSF 3.34-fold. SGE treatment increased production of IL-10 in nonstimulated cultures (Fig. 4) and also production of IL-4 in spirochete-stimulated cells (Fig. 5). Levels of the other cytokines (IL-6, GM-CSF) remained unchanged.

\section{DISCUSSION}

Determination of cytokine production by epidermal cell cultures derived from Borrelia-susceptible $\mathrm{C} 3 \mathrm{H} /$ $\mathrm{HeN}$ mice and resistant $\mathrm{BALB} / \mathrm{c}$ mice revealed that $\mathrm{BALB} / \mathrm{c}$ mice produced higher levels of Th2 cytokines, either spontaneously (IL-4, IL-10) or after stimulation by spirochetes in vitro (IL-6). On the other hand, production of TNF- $\alpha$ was comparable in cultures from both susceptible and resistant mice. Unfortunately, we were not able to induce a measurable production of Th1 cytokines in epidermal cells. Spontaneous production of cytokines by cultures of epidermal cells due to perturbation of the skin by shaving appears unlikely, because the cells had been cultured for several days before use, whereas the cytokine response to the skin perturbation lasts only several hours (Wood et al. 1992).

Our results are in agreement with generally accepted opinion that $\mathrm{BALB} / \mathrm{c}$ mice are $\mathrm{Th} 2$ responders, whereas
$\mathrm{C} 3 \mathrm{H} / \mathrm{HeN}$ mice prefer Th1 response (Kuroda et al. 2000). It is not surprising that the cytokine response of epidermal cells is in correspondence with the response of spleen or lymph node cells. Early cytokine response in the skin can markedly affect the development of the systemic immune response (Shreedhar et al. 1998).

The main objective of the presented research was to estimate the effect of tick SGE on the production of cytokines by mouse epidermal cells stimulated with $B$. afzelii spirochetes. There is no doubt that tick saliva modulates the host immune response towards a Th2 cytokine profile. This effect was demonstrated in vivo after repeated tick infestations (Ferreira and Silva 1999, Schoeler et al. 1999) and in vitro in cultures of mouse splenocytes (Kovár et al. 2002) or human peripheral blood leukocytes (Kováŕ et al. 2001). Few data have been published, however, concerning the effect of tick saliva on the skin immune system. Feeding of noninfected ticks induces an inflammatory reaction characterised by infiltration of granulocytes and monocytes in rabbits (Wheeler et al. 1989) and an increase in CD4+ T lymphocytes and Ia antigens expression on skin dendritic cells and infiltrated monocytes in mice (Mbow et al. 1994a). Epidermal keratinocytes, dermal dendritic cells and infiltrated mononuclear cells expressed mRNA for pro-inflammatory cytokines IL-1 and TNF- $\alpha$ (Mbow et al. 1994a). In infiltrating cells of reinfested mice mRNA for IFN- $\gamma$, IL-2 and IL-4 were detected (Mbow et al. 1994b). These changes characterise the skin immune reaction to tick saliva antigens, some of which are elicited by mechanical injury of the skin by tick mouthparts.

Another immune response is induced by the transmitted pathogen, such as B. burgdorferi spirochetes. Human erythema migrans infiltrates were enriched for $\mathrm{T}$ lymphocytes, dendritic cells and monocytes, contained lower proportions of neutrophils and were devoid of $B$ cells. Neutrophils and macrophages were activated. IL-6 and IFN- $\gamma$ were predominant cytokines in skin lesions. Increased expression of Toll-like receptors was observed on lesional macrophages and dendritic cells (Salazar et al. 2003).

Our results compare cytokines induced in epidermal cell cultures by live $B$. afzelii spirochetes with those induced by spirochetes in the presence of tick SGE. SGE suppressed TNF- $\alpha$ produced by epidermal cells derived from both borrelia-sensitive and borreliaresistant mouse strains. In vitro experiments using LPSstimulated BALB/c-derived peritoneal exudate cells (Ramachandra and Wikel 1992) or macrophage-like cell line JA-4 (Gwakisa et al. 2001) demonstrated SGEmediated suppression of TNF- $\alpha$. Ex vivo cultures of macrophages from repeatedly infested $\mathrm{C} 3 \mathrm{H} / \mathrm{HeN}$ and BALB/c mice, stimulated with LPS, provided equivocal results with a tendency of suppression compared with non-infested mice (Schoeler et al. 1999). 
The first work that tried to cover both the effects of tick saliva and tick-transmitted B. burgdorferi spirochetes on the host cytokine response was published by Zeidner et al. (1997). They compared the cytokine response in Lyme disease-resistant BALB/c mice and susceptible $\mathrm{C} 3 \mathrm{H} / \mathrm{HeJ}$ mice. Infestation of $\mathrm{C} 3 \mathrm{H} / \mathrm{HeJ}$ mice with $B$. burgdorferi-infected Ixodes scapularis ticks resulted in an up regulation of IL-4 and down regulation of IL-2 and IFN- $\gamma$. This Th2 polarisation of the host cytokine response was not evident in BALB/c mice. Similar modulation of the splenocyte cytokine response toward a Th2 pattern was observed after infestation with non-infected ticks. These results are in good correspondence with our observations of the $I$. ricinus SGE effect on epidermal cell cultures from $\mathrm{C} 3 \mathrm{H} / \mathrm{HeN}$ mice. Up regulation of IL-4 in cultures stimulated with spirochetes and up regulation of IL-10 in non-stimulated cultures was demonstrated. In contrast, SGE down regulated expression of IL-10 and IL- 6 in cultures derived from BALB/c mice. The effect on IL-4 was ambiguous. Although it can be supposed that several compartments of the immune system would behave similarly regarding the cytokine polarisation pattern, there are several differences between our experiments and those done by Zeidner et al. (1997). Whereas our epidermal cell cultures were stimulated by spirochetes and influenced by SGE in vitro, Zeidner et al. (1997) used splenocytes from mice infested with Borrelia-infected ticks, that were "restimulated" with concanavalin A ex vivo.

Unfortunately, it is unclear which cells in the epidermal cell culture contribute to cytokine production. We can only speculate that keratinocytes play a significant role in this process, because they represent $90 \%$ of epidermal cells (Wikel 1996). The role of other epidermal cells, such as Langerhans cells or dendritic T lymphocytes, needs further investigation. Also, the immune interaction of epidermal cells with Borrelia spirochetes remains obscure. As outer surface lipoproteins of spirochetes are well-known generalised activators of macrophages (Weis et al. 1994), they can be expected to induce cytokines in Langerhans cells.

There is increasing evidence that both the vector and the transmitted pathogen have evolved mechanisms to manipulate and evade the host immune response. It seems likely that polarisation of the host cytokine response towards a Th2 pattern is advantageous for both of them. The suppressive effect of tick saliva on Th1 immune response inhibits a special form of delayed type of hypersensitivity - cutaneous basophil hypersensitivity operating against tick feeding (Askenase et al. 1979). Similarly, Th1 immunity seems to be important for the control of Borrelia spirochete transmission (Zeidner et al. 1996, 1997). Moreover, Th2-associated cytokines (IL-4, IL-10) exert a strong anti-inflammatory effect in terms of suppression of macrophage functions including production of NO, which represents an important Borrelia killing mechanism (Modolell et al. 1994, Kuthejlová et al. 2001). In this way, immunomodulatory effects of tick saliva facilitate pathogen transmission.

The skin represents the place of first contact with both tick saliva and pathogen to the host immune system. The early polarisation of immunoregulatory cytokines production by skin cells, due to the effect of tick saliva, markedly affects further development of the host systemic immune response.

Acknowledgements. This work was supported by grant no. 524/02/0901 from the Grant Agency of the Czech Republic, the Research project of the Institute of Parasitology, Academy of Sciences of the Czech Republic (Z6 022 909) and by the grant from the Ministry of Education, Youth and Sports (project no. MSM 123100003).

\section{REFERENCES}

ASKENASE P.W., GRAZIANO F., WORMS M. 1979: Immunobiology of cutaneous basophil reactions. Monogr. Allergy 14: 222-235.

BARTHOLD S.W., BECK D.S., HANSEN G.M., TERWILLIGER G.A., MOODY D. 1990: Lyme borreliosis in selected strains and ages of laboratory mice. J. Infect. Dis. 162: $133-138$.

ELBE A., FOSTER C.A., STINGL G. 1997: Isolation of T cells from mouse and human skin. In: I. Lefkovits (Ed.), Immunology Methods Manual. Academic Press, New York, pp. 1490-1501.

ENK A.H., ANGELONI V.L., UDEY M.C., KATZ S.I. 1993: Inhibition of Langerhans cell antigen-presenting function by IL-10. A role of IL-10 in induction of tolerance. J. Immunol. 151: 2390-2398.

FERREIRA B.R., SILVA J.S. 1999: Successive tick infestations selectively promote a T-helper 2 cytokine profile in mice. Immunology 96: 434-439.
FERREIRA B.R., SZABO M.J., CAVASSANI K.A., BECHARA G.H., SILVA J.S. 2003: Antigens from Rhipicephalus sanguineus ticks elicit potent cell-mediated immune responses in resistant but not in susceptible animals. Vet. Parasitol. 115: 35-48.

GWAKISA P., YOSHIHARA K., LONG TO T., GOTOH H., AMANO F., MOMOTANI E. 2001: Salivary gland extract of Rhipicephalus appendiculatus ticks inhibits in vitro transcription and secretion of cytokines and production of nitric oxide by LPS-stimulated JA-4 cells. Vet. Parasitol. 99: 35-61.

HIRSCHFELD M., KIRSCHNING C.J., SCHWANDNER R., WESCHE H., WEIS J.H., WOOTEN R.M., WEIS J.J. 1999: Cutting edge: inflammatory signalling by Borrelia burgdorferi lipoproteins is mediated by toll-like receptor 2. J. Immunol. 163: 2382-2386.

KOPECKÝ J., KUTHEJLOVÁ M., PECHOVÁ J. 1999: Salivary gland extract from Ixodes ricinus ticks inhibits 
production of interferon-gamma by upregulation of interleukin-10. Parasite Immunol. 21: 351-356.

KOVÁŘ L., KOPECKÝ J., ŘÍHOVÁ B. 2001: Salivary gland extract from Ixodes ricinus ticks polarizes the cytokine profile toward $\mathrm{Th} 2$ and suppresses proliferation of $\mathrm{T}$ lymphocytes in human PBMC culture. J. Parasitol. 87: $1342-1348$.

KOVÁŘ L., KOPECKÝ J., ŘÍHOVÁ B. 2002: Salivary gland extract from Ixodes ricinus tick modulates the host immune response towards the Th2 cytokine profile. Parasitol. Res. 88: 1066-1072.

KURODA E., SUGIURA T., ZEKI K., YOSHIDA Y., YAMASHITA U. 2000: Sensitivity difference to the suppressive effect of prostaglandin E2 among mouse strains: a possible mechanism to polarize Th2 type response in BALB/c mice. J. Immunol. 164: 2386-2395.

KUTHEJLOVÁ M., KOPECKÝ J., ŠTĚPÁNOVÁ G., MACELA A. 2001: Tick salivary gland extract inhibits killing of Borrelia afzelii spirochetes by mouse macrophages. Infect. Immun. 69: 575-578.

MATYNIAK J.E., REINER S.L. 1995: T helper phenotype and genetic susceptibility in experimental Lyme disease. J. Exp. Med. 181: 1251-1254.

MBOW M.L., CHRISTE M., RUTTI B., BROSSARD M. 1994a: Absence of acquired resistance to nymphal Ixodes ricinus ticks in $\mathrm{BALB} / \mathrm{c}$ mice developing cutaneous reactions. J. Parasitol. 80: 81-87.

MBOW M.L., RUTTI B., BROSSARD M. 1994b: Infiltration of CD4+ CD8 $+\mathrm{T}$ cells, and expression of ICAM-1, Ia antigens, IL-1 alpha and TNF-alpha in the skin lesion of BALB/c mice undergoing repeated infestations with nymphal Ixodes ricinus ticks. Immunology 82: 596-602.

MODOLELL M., SCHAIBLE U.E., RITTIG M., SIMON M.M. 1994: Killing of Borrelia burgdorferi by macrophages is dependent on oxygen radicals and nitric oxide and can be enhanced by antibodies to outer surface proteins of the spirochete. Immunol. Lett. 40: 139-146.

PECHOVÁ J., ŠTĚPÁNOVÁ G., KOVÁŘ L., KOPECKÝ J. 2002: Tick salivary gland extract-activated transmission of Borrelia afzelii spirochetes. Folia Parasitol. 49: 153-159.

RAMACHANDRA R.N., WIKEL S.K. 1992: Modulation of host-immune responses by ticks (Acari: Ixodidae): effect of salivary gland extract on host macrophages and lymphocyte cytokine production. J. Med. Entomol. 29: 818826.

SALAZAR J.C., POPE C.D., SELATTI T.J., FEDER H.M. Jr., KIELY T.G., DARDICK K.R., BUCKMAN R.L., MOORE M.V., CAIMANO M.J., POPE J.G., KRAUSE P.J., RADOLF J.D. 2003: Coevolution of markers of innate and adaptive immunity in skin and peripheral blood of patients with erythema migrans. J. Immunol. 171: $2660-2670$.
SCHOELER G.B., MANWEILER S.A., WIKEL S.K. 1999: Ixodes scapularis: effect of repeated infestation with pathogen-free nymphs on macrophage and T-lymphocyte cytokine responses of $\mathrm{BALB} / \mathrm{c}$ and $\mathrm{C} 3 \mathrm{H} / \mathrm{HeN}$ mice. Exp. Parasitol. 92: 239-248.

SHREEDHAR V., GIESE T., SUNG V.W., ULLRICH S.E. 1998: A cytokine cascade including prostaglandin E2, IL4 , and IL-10 is responsible for UV-induced systemic immune suppression. J. Immunol. 160: 3783-3789.

STEERE A.C. 1989: Lyme disease. N. Engl. J. Med. 321: 586-596.

STREILEIN J.W. 1983: Skin-associated lymphoid tissues (SALT): origins and functions. J. Invest. Dermatol. 80: 12S-16S.

ŠTĚPÁNOVÁ-TRESOVÁ G., KOPECKÝ J., KUTHEJLOVÁ M. 1999: Identification of Borrelia burgdorferi sensu stricto, Borrelia garinii and Borrelia afzelii in Ixodes ricinus ticks from Southern Bohemia using monoclonal antibodies. Zentralbl. Bakteriol. 289: 797-806.

WEIS J.J., MA Y., ERDILE L.F. 1994: Biological activities of native and recombinant Borrelia burgdorferi outer surface protein A: dependence on lipid modification. Infect. Immun. 62: 4632-4636.

WHEELER C.M., COLEMAN J.L., HABICHT G.S., BENACH J.L. 1989: Adult Ixodes dammini on rabbits: development of acute inflammation in the skin and immune responses to salivary gland, midgut, and spirochetal components. J. Infect. Dis. 159: 265-273.

WIKEL S.K. 1996: Immunology of the skin. In: S.K. Wikel (Ed.), The Immunology of Host-Ectoparasitic Arthropod Relationships. CAB International, Wallingford, Oxon, pp. $1-29$.

WIKEL S.K. 1999: Tick modulation of host immunity: an important factor in pathogen transmission. Int. J. Parasitol. 29: 851-859.

WOOD L.C., JACKSON S.M., ELIAS P.M., GRUNFELD C., FEINGOLD K.R. 1992: Cutaneous barrier perturbation stimulates cytokine production in epidermis of mice. J. Clin. Invest. 90: 482-487.

ZEIDNER N., DREITZ M., BELASCO D., FISH D. 1996: Suppression of acute Ixodes scapularis-induced Borrelia burgdorferi infection using tumour necrosis factor- $\alpha$, interleukin-2 and interferon- $\gamma$. J. Infect. Dis. 173: 187195.

ZEIDNER N., MBOW M.L., DOLAN M., MASSUNG R., BACA E., PIESMAN J. 1997: Effects of Ixodes scapularis and Borrelia burgdorferi on the modulation of the host immune response: induction of a Th2 cytokine response in Lyme disease susceptible $(\mathrm{C} 3 \mathrm{H} / \mathrm{HeJ})$ but not in disease resistant $(\mathrm{BALB} / \mathrm{c})$ mice. Infect. Immun. 65: 3100-3106 